\title{
THE USE OF ICT IN LEARNING PROCESS BY VOCATIONAL TEACHERS OF ENGLISH
}

\author{
Resty Wiranda \\ English Education Department, Faculty of Teacher Training and Education, Sriwijaya University, Indonesia \\ Email: restywirandabayumi@gmail.com \\ Ismail Petrus (Corresponding author) \\ English Education Department, Faculty of Teacher Training and Education, Sriwijaya University, Indonesia \\ Email: ismailpetrus@yahoo.com \\ Machadalena Vianty \\ English Education Department, Faculty of Teacher Training and Education, Sriwijaya University, Indonesia \\ Email: vianty.unsri@gmail.com
}

\begin{abstract}
APA Citation: Wiranda, R., Petrus, I., \& Vianty, M. (2020). The use of ICT in learning process by vocational teachers of English. English Review: Journal of English Education, 8(2), 283-290. doi: 10.25134/erjee.v8i2.2617.
\end{abstract}

\begin{abstract}
In the era of modernization, people are very dependent on technology, Information Communication Technology (ICT) in education itself has important role in teaching and learning process. The purpose of this study was to investigate the kind of ICT used by the teachers, the utilization of ICT in learning process, the problems and solutions in teaching by using ICT, and the role of schools in assisting teachers to overcome the problems at vocational high schools in Sekayu. This study applied descriptive qualitative research design. The data were collected by using questionnaire, interview, observation, and document review. The participants of this study were the teachers of English, the vice-principal of facility and infrastructure, and the students. The findings of this study showed that the teachers of English at vocational high schools in Sekayu used hardware such as projector, laptop, speaker, headset, and smartphone, while software such as internet, dictionary application, e-book, Microsoft office, and browsing application. The teachers used discovery learning to utilize ICT in the syntax of the learning model. The main problem faced by the teacher was the unavailability of students' personal ICT devices. The school also had the role to assist teachers in overcoming the problems. The conclusion was the teachers had applied ICT in the learning process however they did not fully apply ICT in each syntax of the learning model used.
\end{abstract}

Keywords: ICT; the use of ICT; learning process, teachers of English; vocational high school.

\section{INTRODUCTION}

In the $21^{\text {st }}$ century, there have been many changes in several areas such as technology, culture, society, and education. In the era of modernization, people are very dependent on technology, in education itself technology has important role in teaching and learning process, Information Communication Technology (ICT) is defined as 'any technology used to support information gathering, processing, distribution and use' (Beckinsale \& Ram, 2006). In the 21st century the development of information technology is very rapid so that it has a very significant impact on the world of education. One of the most vital contributions of ICT in the field of education is-easy access to learning. It is in line with what Inderawati, Sofendi, Purnomo, Vianty, \&Suhendi (2019) had conducted to the preservice EFL teachers' engagement in utilizing technology for learning supports. It showed that there were many things to be included: the place, class management, equipment used by students, application used, instructional material used, supporting crew, and instructors' relation in learning activities. With the help of ICT, students can browse information through e-books, sample examination papers, previous year papers etc. and can also have an easy access to resource persons, mentors, experts, researchers, professionals, and peers-all over the world. This flexibility has heightened the availability of just-in-time learning and provided learning opportunities for many more learners who previously were constrained by other commitments (Young, 2002). In addition to flexibility in usability, ICT is also considered flexible in time space, as explained by Julio and Carmen (2013), the flexible time space accounted for by the integration of ICT into teaching and learning processes contributes to increase the interaction and reception of 
information. ICT also can be used in various ways where it helps teachers and students to learn about their respective subject areas, as stated in the 2013 curriculum, Information and Communication Technology (ICT) is integrated into learning. Inderawati (2017) put forward that modern classroom must become technology as the essential key component in the $21^{\text {st }}$ century learning.

UNESCO (2016) stated that there are five competencies for the teacher in the $21^{\text {st }}$ century, one of them is the use of ICT in the process of teaching to prepare and to support the learning competencies in their classroom. This makes a teacher obliged to master ICT in learning. The role of ICTs becomes very important in the learning process because it can improve the efficiency and effectiveness of learning so that it can increase the attractiveness and attention of students. The global expectation to ICT in education from Ministrial Regulation of National Education and Culture of Republic of Indonesia No. 22 Year 2016 Chapter I explained that the use of information and communication technology is to improve efficiency and effectiveness of learning. Inderawati, Agusta, \&Sitinjak (2018) found that mobile learning as one of the modes of learning had a potential effect on students' reading achievement.

However, it is not relevant with the facts from Weaver and Pier (2011) explained that entering the 21 st century which is full of technology does not make students more creative and energetic, instead it decreases student communication skills. Weaver and Pier's research was strengthened by a survey conducted by NACE (National Association of Colleges and Employers) in 2017 indicating that as many as $67.5 \%$ of students had low communication skills. Some studies related to the use of ICT by the teacher, such as the study conducted by Fitriyadi (2012). The results of this study showed that the Vocational High School productive teachers' ICT skills in general are in the low category, the ICT implementation in productive teaching in Vocational High School in general is in the moderate category, and the constraints in the ICT implementation in productive teaching in Vocational High School are related to the local government's policies, program funding, professional development in ICT, availability of ICT resources, and ICT utilization in schools. Other study by Miraj (2017) showed that the use of ICT (computers, Internet) has been used by students of vocational high school, however usability of ICT does not fully support the learning process. The government's expectation on ICT has not been achievable because there are some obstacles found from some research results. These results show that there are many obstacles faced by both teachers and schools in implementing ICT in schools. Nevertheless, some previous researchers have investigated the important roles of technology in learning English to enhance students' literacy (Inderawati, 2011; Fajri, Inderawati, Mirizon, 2015; Inderawati, Petrus, \& Jaya, 2019).

According to Djojonegoro (1998) a good vocational high school is responsively and anticipatory to technological progress. Based on the observation the researcher did at three vocational high schools in Sekayu, the schools had implemented ICT in the teaching and learning process. Technology-based education is also supported by the MUBA government with the vision and mission of the MUBA regent as follows: "Realizing the Smart Musi Banyuasin Regency with the entire OPD digitalization program. The service is integrated in realizing optimal, efficient and transparent governance in providing information access". In addition, the data obtained by researchers from the three schools are that there are three majors in vocational high schools in Sekayu related to technology, such as: Multimedia, Technology of science, and computer engineering and networking. One of the objectives of this study is to find out what media are used by teachers in the teaching and learning process, considering the students in this majors have a background with the ability in the field of ICT.

In relation to the explanation above, the aims of this study were to find out the kind of ICT used by the teachers of English, the utilization of ICT used by teachers of English in learning process, the problems and solutions in teaching by using ICT, and the role of schools in assisting teachers to overcome the problems.

\section{METHOD}

This study was a descriptive qualitative research conducted through data collection in field through interview, questionnaire, observations and document review, to find out The kinds of ICT used by teachers of English in Vocational High Schools in Sekayu, the utilization of ICT by teachers of English in the classroom, the problems faced by teachers of English in teaching by using ICT and the solution to overcoming the problems, the role of schools in assist teachers of English in 
overcoming the problems faced by teachers of English towards ICT.

This study was conducted at three vocational high schools in Sekayu: vocational high school 1 in Sekayu, Vocational High School 2 in Sekayu, and Vocational High School 3 in Sekayu. These three schools are selected because they have received to ICT facilities, such as: free internet access, electric power, LCDs, laptops from the government.

The participants of this study were the teachers of English, the vice-principal of facilities and infrastructure each school and students. The five teachers of English selected in each school based on the observation the writer did on vocational high school in Sekayu there were five teachers who teach in major related to ICT who are willing to be participants in this study.

To collect the data, the researcher used four instruments. The instruments included interview, questionnaire, observation, and document. After the data was collected, the writer analyzes for answer the research questions. Questionnaire was analyzed by a simple statistical analysis that is by calculating the respondents' answers from each item and putting the answer in the form of percentage. The results of questionnaire are transcribed descriptively used for showing the problems faced by teachers of English in teaching by using ICT and the solution of the problem. While, for the interview is transcribed descriptively. In order to obtain supporting information for interview results, observation technique was conducted. The researcher took some pictures and writing a comment in observation paper during teaching and learning process, after obtaining the results, then the transcribed descriptively in order to strengthen the interview results. Lastly, the documents collected from lesson plan that used during the observation analyzed by responses to the research question.

This study used triangulation to determine validity by analyzing from various perspectives. Denzin (2006) stated that triangulation is the process of corroborating evidence from different individuals. Based on the types of triangulation, the study used Methodological triangulation. Therefore, data triangulation helped the writer to justify the findings and results of this study.

\section{RESULTS AND DISCUSSION}

The results of this study cover four areas. They are the result of questionnaire to the teachers, interview to the teacher of English, the viceprincipal of facilities and infrastructure in each Vocational High School in Sekayu, and students, observation in classroom during learning process, and document collected from lesson plan that used during the observation.

\section{Hardware and Software used by the teachers}

The results of interviews conducted by researchers showed that all the teachers at the Vocational School in Sekayu had applied ICT in the learning process. The ICT they use also varies. The following are the statements from the teachers.

"I utilized a smartphones for browsing and access to the Google Translate application, and I have received permission from the school to allow students to use their smarphones during my lessons." (EY)

"... and I used the language laboratory for the study room where I can access some electronic learning media, such as: e-books, videos, audio and visuals. And for the hardware I used to use computers, projectors, and speakers." (AG)

"Sometimes I use laptops and projectors to
display material on power point. Although I didn't
use in every teaching because at school only
provides one laptop and LCD for one major.
While laptops and LCDs were more prioritized for
teachers from productive subjects" (I)

"ICT facilities available at the school are WIFI for, LCD and laptop and from that facility I used LCD and WIFI" (NMA)

"At vocational high school 3 in Sekayu, it provides a language laboratory equipped with computers, projectors, TVs, speakers, headsets, and WIFI even though WIFI can only be used by teachers and students cannot use it because many users are feared to slow down internet connections. Sometime I use a laptop and LCD available in the language laboratory, and WIFI." (SH)

The data of interview was relevant to the data of observation and the lesson plan that used during the observation. The Table 1 shows the results of hardware and software used by the teachers. 
Table 1. ICT used by the teachers of English at vocational high school in Sekayu

\begin{tabular}{|c|c|c|c|}
\hline \multirow[b]{2}{*}{ Schools } & \multicolumn{3}{|c|}{ ICT used by the teachers of English } \\
\hline & Teachers & Hardware & Software \\
\hline \multirow[t]{2}{*}{$\begin{array}{l}\text { Vocational High School } \\
1 \text { in Sekayu }\end{array}$} & EY & Smartphone & $\begin{array}{c}\text { Internet and applications (dictionary } \\
\text { application and browsing } \\
\text { application) }\end{array}$ \\
\hline & $\mathrm{AG}$ & $\begin{array}{c}\text { Laptop,projector, speaker, and } \\
\text { headset }\end{array}$ & Internet and E-book \\
\hline $\begin{array}{l}\text { Vocational High School } \\
2 \text { in Sekayu }\end{array}$ & I & Projector and laptop & Microsoft office (power point) \\
\hline \multirow{2}{*}{$\begin{array}{l}\text { Vocational High School } \\
3 \text { in Sekayu }\end{array}$} & NMA & Projector and laptop & Internet \\
\hline & $\mathrm{SH}$ & Projector and laptop & Internet \\
\hline
\end{tabular}

The kinds of ICT used by the teachers of English at vocational high school in Sekayu are divided into hardware and software. In line with Anderson and Glend (2003) defined Information and Communication Technology (ICT):

ICT generally relates to those technologies that are used for accessing, gathering, manipulating and presenting or communicating information. The technologies could include hardware e.g. computers and others devices, software applications, and connectivity e.g. access to the internet, local networking infrastructure, and video conferencing.

In conclusion the hardware used by teachers of English at vocational high schools in Sekayu includes: projectors, laptops, computers, speakers, and headsets. While for software including: internet, e-book, and electronic dictionary. In line with the study by Prasanea (2017) the finding showed the use of hardware such as: television, computers and sound systems make students more easily understand the material presented.

\section{The utilization of ICT}

The kinds of ICT chosen by the teachers is utilized in assisting the learning process, one of the ICT is Smartphone. In line with Wastiau et al. (2013) note that laptop and tablet computers as well as cell phones are increasingly seen as useful in education as they offer portability and choice as to when and where to use them.From the results of observation and document, the all of the teachers who participated in this study used Discovery Learning as a learning model, however each teachers used ICT only part of the syntax in Discovery Learning and every teachers have a different method in utilizing ICT in learning process. It was also stated in an interview, the Table 2 were describe the result of interview.

Table 2. The utilization of ICT by the teachers of English at vocational high school in Sekayu

\begin{tabular}{|c|c|c|c|c|}
\hline Schools & Teachers & $\begin{array}{c}\text { Learning } \\
\text { media }\end{array}$ & Syntax & ICT use \\
\hline & EY & $\begin{array}{c}\text { Discovery } \\
\text { learning }\end{array}$ & Data collection & Smartphone and internet \\
\hline $\begin{array}{l}\text { Vocational } \\
\text { High School } 1 \\
\text { in Sekayu }\end{array}$ & $\mathrm{AG}$ & $\begin{array}{l}\text { Discovery } \\
\text { learning }\end{array}$ & $\begin{array}{l}\text { Stimulation and } \\
\text { data collection }\end{array}$ & $\begin{array}{l}\text { Stimulation: Laptop, } \\
\text { projector, speaker, and } \\
\text { headset } \\
\text { Data collection: internet and } \\
\text { E-book }\end{array}$ \\
\hline $\begin{array}{l}\text { Vocational } \\
\text { High School } 2 \\
\text { in Sekayu }\end{array}$ & I & $\begin{array}{l}\text { Discovery } \\
\text { learning }\end{array}$ & Stimulation & Projector and laptop \\
\hline \multirow{2}{*}{$\begin{array}{l}\text { Vocational } \\
\text { High School } 3 \\
\text { in Sekayu }\end{array}$} & NMA & $\begin{array}{l}\text { Discovery } \\
\text { learning }\end{array}$ & $\begin{array}{l}\text { Stimulation and } \\
\text { data collecting }\end{array}$ & $\begin{array}{l}\text { Stimulation: projector and } \\
\text { laptop } \\
\text { Data collecting: internet }\end{array}$ \\
\hline & $\mathrm{SH}$ & $\begin{array}{l}\text { Discovery } \\
\text { learning }\end{array}$ & $\begin{array}{l}\text { stimulation data } \\
\text { collection, and } \\
\text { generalization }\end{array}$ & $\begin{array}{l}\text { Stimulation: projector and } \\
\text { laptop } \\
\text { Data collecting: internet }\end{array}$ \\
\hline
\end{tabular}


In conclusion, the all teachers utilize ICT in the core activities where all teachers use Discovery learning as a learning model but ICT is only used for a few syntaxes, such as: stimulation, data collection, and generalization.

The utilization of ICT in the learning process could be seen from the learning model used by the teachers. The syntax of the learning model would show the teacher's activities in teaching using ICT. There were several learning models that are used in the learning process and involve the role of ICT as a learning media. There are 4 learning models that are generally used based on Ministry of Education and Culture number 22 year 2016 stated that learning model that brings out activity and creativity, inspiring, fun and initiative, centered on students, authentically, Contextual, and meaningful to daily student life. The learning models are developed, among others: Discovery learning, Inquiry learning, Problem Based learning, and Project Based Learning.

\section{The Problem and Solution in Using ICT}

From the results of the interview and questionnair, the teachers in each school found several problems in applying ICT in the learning process. In addition, they also have their own way of dealing with the problem. The problems faced by the teachers of English at vocational high school in Sekayu as shown in Table 3.

Table 3. The problem and solution of the problems faced by the teachers of English at vocational high school in Sekayu

\begin{tabular}{|c|c|c|c|}
\hline Schools & Teachers & Problems & Solutions \\
\hline \multirow[t]{3}{*}{$\begin{array}{l}\text { Vocational High } \\
\text { School } 1 \text { in } \\
\text { Sekayu }\end{array}$} & EY & School regulation & $\begin{array}{l}\text { asking permission from the school to } \\
\text { students are allowed to use } \\
\text { Smartphones during English lessons }\end{array}$ \\
\hline & $\mathrm{AG}$ & $\begin{array}{l}\text { The awareness of students in } \\
\text { maintaining school facilities. }\end{array}$ & $\begin{array}{l}\text { 1. giving advice and punishment to } \\
\text { students }\end{array}$ \\
\hline & & unavailability of technicians & $\begin{array}{l}\text { 2. repairing the damage by themselves } \\
\text { or asking student for help }\end{array}$ \\
\hline \multirow[t]{3}{*}{$\begin{array}{l}\text { Vocational High } \\
\text { School } 2 \text { in } \\
\text { Sekayu }\end{array}$} & I & $\begin{array}{l}\text { unavailability of students' } \\
\text { personal ICT devices to giving } \\
\text { homework }\end{array}$ & $\begin{array}{l}\text { giving students more time to collected } \\
\text { assignment (homework) }\end{array}$ \\
\hline & NMA & $\begin{array}{l}\text { unavailability of students' } \\
\text { personal ICT devices to make } \\
\text { learning group in social media }\end{array}$ & $\begin{array}{l}\text { only use the English lesson time to } \\
\text { discussing and sharing }\end{array}$ \\
\hline & $\mathrm{SH}$ & $\begin{array}{l}\text { unavailability of students' } \\
\text { personal ICT devices to access } \\
\text { the internet }\end{array}$ & dividing students into groups \\
\hline
\end{tabular}

The data conducted by interview and questionnaire to the teachers. The most common problem faced by the teachers of English at vocational high schools in Sekayu were unavailability of students' personal ICT devices. The teachers' statement to support this data is below.

“...I find problems where students do not have personal's ICT devices to work on tasks using ICT for example: typing papers, making discussion material using power points, discussions on Facebook". (I)

"I have a plan to create a study group on social media to become their members for discussion and sharing because in my opinion the school time is only two hours of study and it is still very lacking,
I also want students to do independent assignments at home using the Edmodo application because this application is automatic correct and score so it is very effective. But not all of my

students can access the internet or have their own laptop. "(NMA)

"The problem I faced was that not all students at Vocational High School 3 in Sekayu had ICT devices to use outside of school hours so that I sometimes chose not to give assignments that needed ICT devices. "(SH)

The most common problem faced by the teachers of English at vocational high schools in Sekayu were unavailability of students' personal 
ICT devices as discussed in the study from around the world about ICT in Education, Young (2003), the students identified three negative reasons were also given. Computer access to those students who did not have computer at home. Lack of home computer access to those students at disadvantage because they can only use class time and class breaks to access computers in the computer lab. Although the problems they faced were the same namely unavailability of students support ICT devices, each teachers faced this problem in the application of ICT with different goals, as shown in the table 3 , so that three out of five teachers who faced this problem have their own ways in overcome the problem.

\section{How the schools assist teachers}

The results of interview were gained from the teachers and the vice-principal facility and infrastructure. The results showed that the role of each schools in assisting the teachers' problems. The following are the statements of the viceprincipal facility and infrastructure.

"We always coordinate with the teacher to ask what ICT equipment is needed and then we will submit it to the principal so that the facility is immediately provided if from the results of discussion and consideration of the principal that the device is indeed needed and the lack of awareness of students in maintaining school facilities, We always support every teacher's policy during the learning process. For teachers who face problems related to school regulations, we have coordinated with these teachers and have given permission for students to use smartphones during English lessons. "(AD)

"For this problem I can only advise the teacher to give another alternative task to these students or can divide students into groups so that students who do not have ICT devices can join students who have ICT facilities because the school does not facilitate students to use laboratories outside school hours". (DM)

"So it is true that at Vocational High School 3 not all students come from capable families, so there are only a few students who have laptops and other ICT devices. But in schools students can use laptops and the internet in the laboratory”. (MS)

The role of schools in assisting teachers in overcoming the problem is presented in Table 4.

Table 4. The role of schools in assist teachers of English in overcoming the problem faced by the teachers

\begin{tabular}{|c|c|c|c|}
\hline Schools & Teachers & Problems & $\begin{array}{c}\text { The role of schools in assist } \\
\text { teachers of English in overcoming } \\
\text { the problems }\end{array}$ \\
\hline \multirow[t]{2}{*}{$\begin{array}{l}\text { Vocational High } \\
\text { School } 1 \text { in Sekayu }\end{array}$} & EY & School regulation & $\begin{array}{l}\text { giving permission for students to } \\
\text { used Smartphones during English } \\
\text { lessons }\end{array}$ \\
\hline & $\mathrm{AG}$ & $\begin{array}{l}\text { 1. The awareness of students } \\
\text { in maintaining school } \\
\text { facilities. } \\
\text { 2.unavailability of } \\
\text { technicians }\end{array}$ & $\begin{array}{l}\text { 1. support teachers and repair } \\
\text { damaged facilities } \\
\text { 2. Asking teachers to report to the } \\
\text { vice-principle of facilities and } \\
\text { infrastructure if there are facilities } \\
\text { that need to be added or damaged. }\end{array}$ \\
\hline $\begin{array}{l}\text { Vocational High } \\
\text { School } 2 \text { in Sekayu }\end{array}$ & I & $\begin{array}{l}\text { unavailability of students } \\
\text { support ICT devices to } \\
\text { giving homework }\end{array}$ & $\begin{array}{l}\text { The school only appealed to the } \\
\text { teacher to give another alternative } \\
\text { task to these students or can divide } \\
\text { students into groups }\end{array}$ \\
\hline \multirow[t]{2}{*}{$\begin{array}{l}\text { Vocational High } \\
\text { School } 3 \text { in Sekayu }\end{array}$} & NMA & $\begin{array}{l}\text { unavailability of students' } \\
\text { personal ICT devices to } \\
\text { make learning group in } \\
\text { social media }\end{array}$ & $\begin{array}{l}\text { Only use the English lesson time to } \\
\text { discussing and sharing }\end{array}$ \\
\hline & $\mathrm{SH}$ & $\begin{array}{l}\text { unavailability of students } \\
\text { support ICT devices to } \\
\text { access the internet }\end{array}$ & $\begin{array}{l}\text { internet access for students is being } \\
\text { submitted to the principal to } \\
\text { increase the capacity of the internet } \\
\text { connection }\end{array}$ \\
\hline
\end{tabular}

In conclusion, schools have an important role in facilitating teachers to utilize ICT as a learning medium given that these three schools have used the 2013 curriculum where technology is a 
learning medium that must be applied to learning media as coincides with the result of the study conducted Fitriyadi (2012), the constraints in the ICT implementation in productive teaching in Vocational High School are related to the local government's policies, program funding, professional development in ICT, availability of ICT resources, and ICT utilization in schools.

In the era of modernization, people are very dependent on technology, in education itself technology has important role in teaching and learning process according to Ministrial Regulation of National Education and Culture of Republic of Indonesia No. 22 Year 2016 Chapter I, it states that the use of information and communication technology is to improve efficiency and effectiveness of learning as of the role of schools in facilitating and assisting teachers in dealing with problems during the application of ICT in the learning process is very needed.

\section{CONCLUSION}

This study investigated the kind of ICT used by the teachers, the utilization of ICT in learning process, the problems and solutions in teaching by using ICT, and the role of schools in assisting teachers to overcome the problems at three vocational high schools in Sekayu. This study concluded that the kinds of ICT used by the teachers divided into hardware such as: projector, laptop, speaker, headset, and smartphone, while program such as: internet, e-book, Microsoft office, dictionary application and browsing application. The teachers had utilized ICT in the learning process however the teacher did not fully utilized ICT in each syntax of the learning model used. Moreover, the descriptive analysis of the results showed that the main problem is the unavailability of students' personal ICT devices was important problem. The main solution proposed by teachers was asking student to used Smartphone. the schools also had different ways in assisting teachers in overcoming the problems related to ICT. The conclusion was the teachers have applied ICT in the learning process however the teacher did not fully apply ICT in each syntax of the learning model used. Moreover, the unavailability of students' personal ICT devices was another important problem in giving assignments, motivating students to prepare material for the next meeting, and for accessing the internet.

\section{REFERENCES}

Anderson, J. \& Glenn, A. (2003). Building capacity of teachers facilitators in technology-pedagogy integration for improved teaching and learning: final report. Bangkok: UNESCO, Asia and Pacific Regional Bureau for Education. Retrieved from:

www.unescobkk.org/fileadmin/user_upload/ict/e book/ICTBuilding_capacity/BuildingCapacity.pd f.

Beckinsale, M., \& Ram, M. (2006). Delivering ICT to ethnic minority businesses: An action- research approach. Environment and Planning $C$ : Government and Policy, 24(6), 847 - 886.

Denzin, N. (2006). Sociological methods: A sourcebook ( $5^{\text {th }}$ ed.). Aldine Transaction. ISBN 978-0-202-30840-1.

Djojonegoro, W. (1998). Pengembangan sumber daya manusia melalui Sekolah Menengah Kejuruan. Jakarta, Indonesia: PT. Jayakarta Agung Offset.

Fajri, H, M., Inderawati, R., \& Mirizon, S. (2015). The implementation of peer editing technique to improve writing achievement. The Journal of English Literacy Education: The Teaching and Learning of English as a Foreign Language, 2(2), 48-57.

Fitriyadi, H. (2012). Integrasi teknologi informasi komunikasi dalam pendidikan. Jurnal Pendidikan TeknologidanKejuruan, 21(3), 269284.

Inderawati, R. (2011). From classroom to peer comment in Facebook: Bridging learners' literacy. Paper presented in the $4^{\text {th }}$ International Conference ICT for Language Learning. Pixel, Italy.

Inderawati, R. (2017). The dynamics of EFL teaching in Indonesia: Be innovative teachers through social media. English Language Teaching and Research, 1(1), 29-37.

Inderawati, R., Agusta, O. \&Sitinjak, M. (2018). The potential effect of developed reader response strategy-based mobile reading for students' establishing character and comprehension achievement. Indonesian Journal of Informatics Education, 2(2), 117-126.

Inderawati, R., Petrus, I., \& Jaya, H. P. (2019). Exploring and identifying technology-based dynamic learning through social media in academic writing. English Community Journal, 3(1), 317-324.

Inderawati, R., Sofendi, Purnomo, M. E., Vianty, M., \& Suhendi, D. (2019). Students' engagement in utilizing technology for learning support. ENGLISH FRANCA: Academic Journal of English Language and Education, 3(2), 181-195.

Julio, A., \& Carmen, L. (2013). Application of expert judgment as an evaluation technique for information and communication technologies (ICT). Eduweb Revista de Tecnología de 
Resty Wiranda, Ismail Petrus \& Machadalena Vianty

The use of ICT in learning process by vocational teachers of English

Información y Comunicaciónen Educación, 7(1), 11-22.

Ministrial Regulation of National Education and Culture of Republic of Indonesia. (2016). Government regulation no. 22 tahun 2016. Retrievedfrom: bsnpindonesia.org/.../Permendikbud_Tahun2016_No mor022_L...

Miraj, Y. Z., Rohendri. D, Yanuar, Nurhabibah, \& Wendi, H. F. (2017). ICT literacy of vocational high school students. Materials Science and Engineering. $\quad$ doi: $10.1088 / 1757-$ 899x/306/i/012138.

National Association of Colleges and Employeers. (2017). The key attributes employers seek on students' resumes. Retrieved from http://naceweb.org/about-us/press/2017/the-keyattributes-employers-seekon-students'-resumes at 13 August 2018.

Prasanea, J. T. (2017). The use of Information and Communication Technology in English Classes at Vocational High Schools un Ambon. Paper presented at International Seminar on Language,
Education, and Culture, Malang, Indonesia.

Retrieved from: http://sastra.um.ac.id/wpcontent/uploads/2017/11/110-115-Joke-ThabitaPasanea-edited_LAYOUTED.pdf.

UNESCO. (2016). Preparing \& supporting teachers to meet the global challenges of $21^{\text {st }}$-century learning in Asia- Pacific. Bangkok: Education sector.

Wastiau, P., Blamire, R., Kearney, C., Quittre, V., Van de Gaer, E., \& Monseur, C. (2013). The use of ICT in education: A survey of schools in Europe. European Journal of Education, 48(1), 11-27.

Weaver, K.D., \& Pier, P.M. (2010). Embedded information literacy in the basic oral communication course: From conception through assessment. Public Service Quarterly, 6(3), 259270.

Young, S. C. (2003). Integrating ICT into second language education in a vocational high school. Journal of Computers Assisted Learning, 19, 447-461.

Young, J. (2002). The 24-hour professor. The Chronicle of Higher Education, 48(38), 31-33. 